\title{
Menkes kinky hair disease: A case report
} Asok K Datta*1, Taraknath Ghosh ${ }^{1}$, Kaustav Nayak ${ }^{1}$ and Mrinalkanti Ghosh ${ }^{2}$

\author{
Address: ${ }^{1}$ Department of Pediatrics, Burdwan Medical College, Burdwan-713101, West Bengal, India and ${ }^{2}$ Department of Radiology Burdwan \\ Medical College, Burdwan-713101, West Bengal, India \\ Email: Asok K Datta* - drasokdatta@yahoo.co.in; Taraknath Ghosh - dr.ghosh_taraknath@rediffmail.com; \\ Kaustav Nayak - kaustav25@yahoo.co.in; Mrinalkanti Ghosh - mrinalkanti_ghosh@yahoo.com \\ * Corresponding author
}

Published: 18 September 2008

Cases Journal 2008, I:158 doi:10.1186/1757-1626-I-158

This article is available from: http://www.casesjournal.com/content/I/I//58

tral Ltd.

This is an Open Access article distributed under the terms of the Creative Commons Attribution License (http://creativecommons.org/licenses/by/2.0), which permits unrestricted use, distribution, and reproduction in any medium, provided the original work is properly cited.

\begin{abstract}
An eight month old male infant with protein energy malnutrition was admitted in the hospital with the history of repeated attacks of convulsion since four months of age. He was also suffering from frequent attacks of cough and cold since 6 months of age which was marked prior to admission. The infant had fair complexion, sparse fuzzy wooly hair with marked trunkal hypotonia. He had also mental retardation. Serum copper and ceruloplasmin levels were low, MRI showed prominent extraaxial spaces with gliosis, MR angiography revealed tortuosity of cerebral vessels. Microscopic examination of hair revealed pili torti. The patient was diagnosed as Menkes disease and treated symptomatically. For lack of facilities we were not able to do genetic study.
\end{abstract}

\section{Introduction}

Menkes disease is an X-linked lethal multi system disorder caused by disturbances of copper distribution in different tissues due to mutation of p ATPase7 gene. The estimated prevalence of the disease is 1 in 100000 to 1 in 250000 [1]. The affected individual suffers from malfunction of copper containing enzymes resulting in multi systemic disturbances. Nervous system problems include gross mental retardation, convulsions, cortical atrophy, asymptomatic subdural effusion, grosss trunkal hypotonia and progressive neurological deterioration, Vascular problems with weak collagen tissues causes easy breakability, connective tissue abnormality gives rise to characteristics steel, fuzzy, wooly, sparse hair with easy pluckability [2].

The bones are osteopenic. There are chances of recurrent infections and as a result the infant fails to thrive and malnutrition is a common finding [3]. The infant usually die within 3-4 years of age. In 1962, Menkes first described the syndrome and Drank et.el noted the association with copper metabolism [4]. The affected gene was cloned in 1993.

\section{Case report}

An eight month old male hindu tribal infant from a rural area Tatarpur, Memary, Burdwan, a product of nonconsanguineous marriage, admitted in the hospital with the chief complaint of recurrent attacks of convulsion since four months of age, recurrent respiratory difficulty since six months of age which was aggravated for last seven days and associated with fever. The mother also informed that her baby was lagging in growth and development in comparison to the other children of same age and sex in the community. The child had admitted twice before with bronchopneumonia. The infant has three brothers. Eldest one is 5 years, middle one died at fifteen days after birth. They live in a nuclear family in a mud built 2 rooms house with no sanitary latrine, drink water from tube-well, take bath in pond, parents are labourer with monthly income approximate rupees one thousand only. 
The baby was exclusively breastfed for 4 months, weaning done with suji, biscuits, rice, dal etc which are continuing till now. On examination the baby was conscious but irritable, fair complexion chubby cheeks, light coloured steel sparse wooly hair with easy pluckability (Figure 1). Anthropometric measurement revealed weight $4.5 \mathrm{~kg}$, length $63 \mathrm{~cm}$, head circumference $40.5 \mathrm{~cm}$, chest circumference $36.5 \mathrm{~cm}$, there was mild pallor, skull, spines and bones were normal. pulse 90/min, B.P. 70/50 mm Hg, respiratory rate $55 / \mathrm{min}$, temperature - normal. Central nervous system examination revealed repeated myoclonic seizures of the limbs, Limbs were hypertonic whereas the trunk was hypotonic, generalised muscle wasting present with power grade 3/5 Examination of Respiratory system showed features of pneumonia. Other systems appeared normal.

On investigation the infant was found suffering from mild anemia $(\mathrm{Hb}=9 \mathrm{gm} \%)$, total leucocyte count was increased $16000 / \mathrm{dl}$ due to chest infection, cerebrospinal fluid study was normal, chest X-ray showed pneumonitis and the ribs were found osteopenic. The skeletal survey of the limb bones also showed osteopenia. The serum copper level was $10.25 \mathrm{microgram} / \mathrm{dl}$ ( normal value at this age is 46 to $80 \mathrm{microgram} / \mathrm{dl}$ ),serum ceruloplasmin level was $7.3 \mathrm{mg} / \mathrm{dl}$ (normal value is approximately 20 to 40 $\mathrm{mg} / \mathrm{dl}$ ). The MRI study of the brain revealed prominent bilateral extra-axial C.S.F. spaces with gliosis in both posterior parieto-occipital area with prominent left lateral ventricle and cerebellar folias (Figure 2). MR angiography revealed tortuosity of the cerebral vessels(Figure 3). EEG showed gross generalized polyspike waves. Opthalmoscopic examination showed pale optic disc. Microscopic examination of hair revealed classical sign of pili torti (Figure 4).

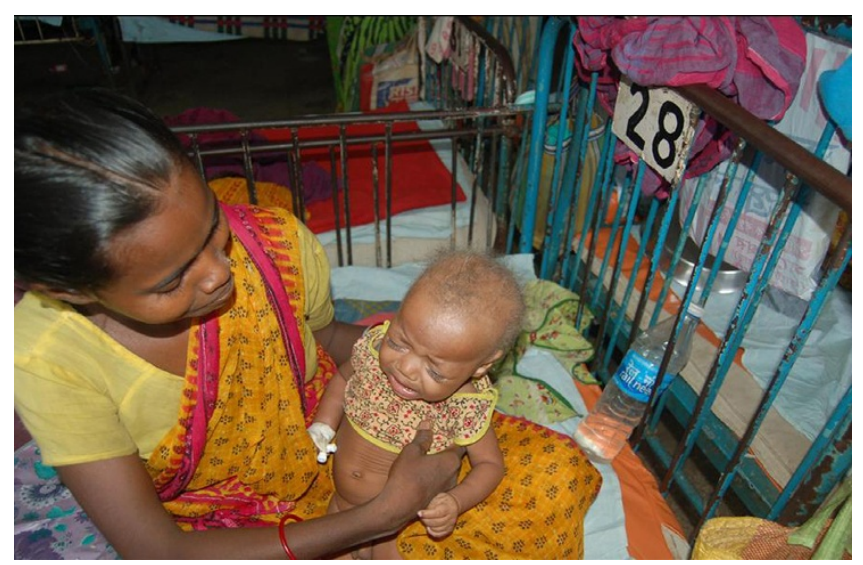

Figure I

It shows the phenotypic appearance of the baby - the characteristics steel fuzzy sparse hair, fair complexion, The chubby cheeks, irritable baby.

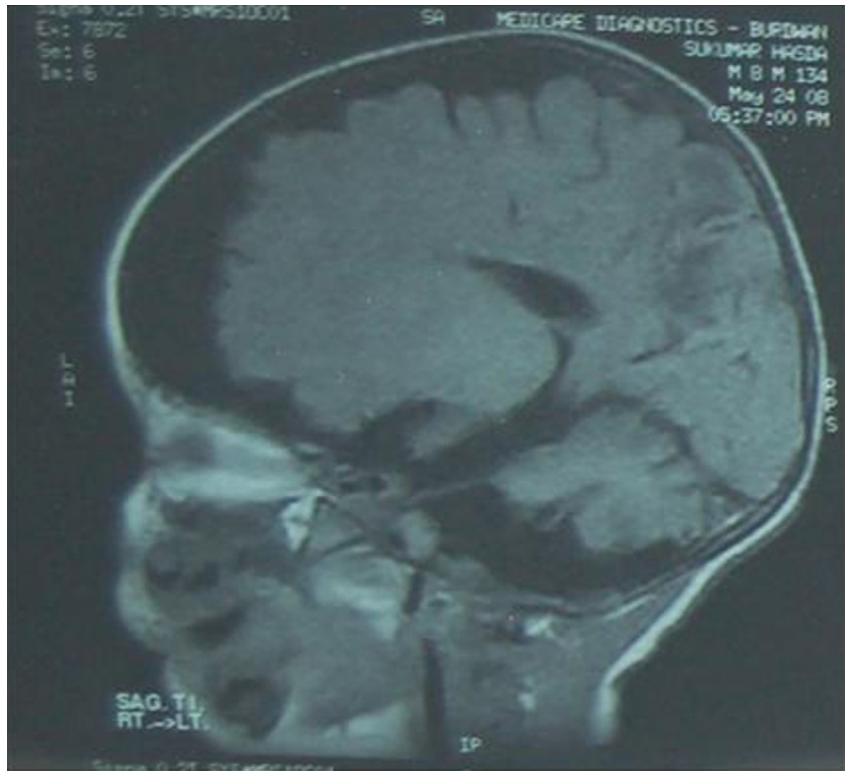

Figure 2

The MRI study of the brain revealed prominent bilateral extra-axial C.S.F. spaces with gliosis in both posterior parieto-occipital area with prominent left lateral ventricle and cerebellar folias.

Because of lack of facility, genetic study is not possible in this case. Because copper histidinate or copper acetate is not available no definite treatment could be done. The child was treated symptomatically with anticonvulsive drugs and antibiotics for pneumonia and discharged. The parents were advised for monthly follow up.

\section{Discussion}

Menkes disease is an $\mathrm{X}$ - linked disorder resulting in profound systemic copper deficiency. The Menkes disease

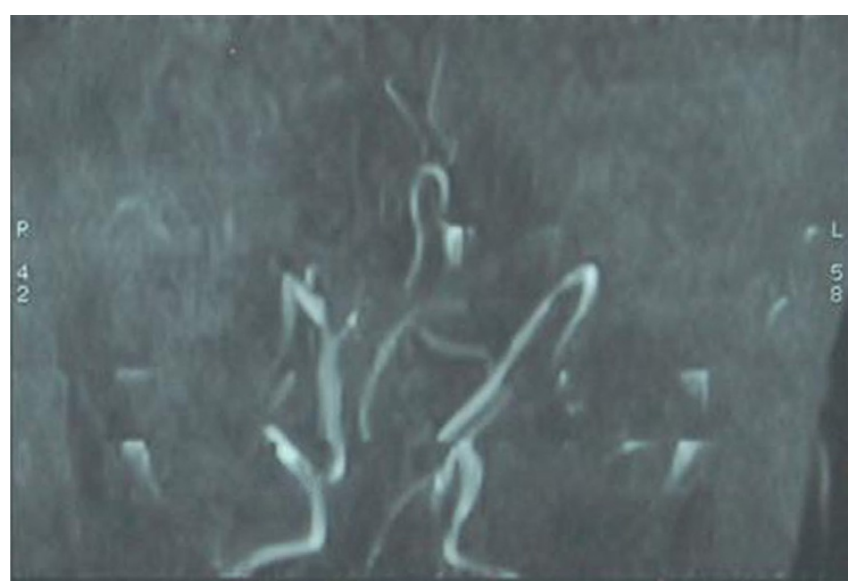

Figure 3

MR angiography reveals tortuosity of the cerebral vessels with hairpin like bending. 


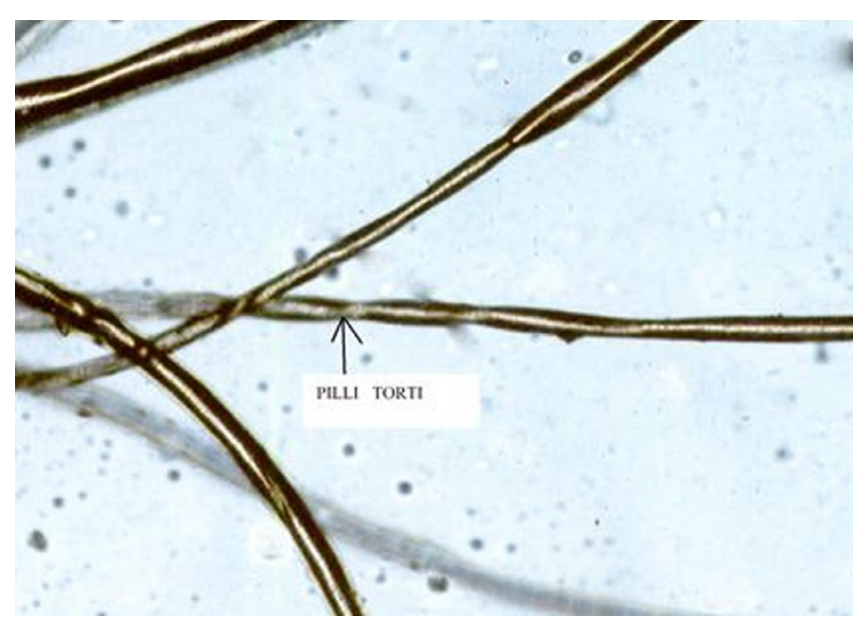

Figure 4

Microscopic examination of hair revealed classical sign of pili torti.

gene is (ATP7A) encodes an enzyme p type ATPase which is required for systemic absorbtion, distribution and metabolism of copper in tissues. There is no race prediliction. The disease usually manifests at the age of 2-3 month and usually die at 3-4 years of age due to pneumonia. Our patient presented at the age of 4 months.

Molecular studies have shown gene defect and more than 150 of different mutations of the Menkes gene are reported $[5,6]$. The maldistribution of copper occur in different tissues e.g. accumulation in muscles, kidneys, spleen and pancreas but low in liver and brain. The serum copper concentration is low. Copper dependent enzymes like cytochrome oxidase concerned with electron transport and ATP formation, tyrosinase concerned with the pigment melanin synthesis, lysyl oxidase concerned with collagen synthesis, superoxide dismutase an antioxidant, enzyme for catecholamine biosynthesis and peptidylglycin alpha amidating monoxidase concerned with activation of neuropeptide are not functioning properly [7].

Menkes disease results in developmental delay, seizures, hypotonia which is more in trunkal muscle and feeding difficulties. All these are marked in our patient. The characteristics facies, fair complexion, chubby cheeks, sparse twisted fuzzy depigmented hair are all present in our case. The investigation finding of low serum copper, ceruloplasmin, hair structures are characteristics of Menkes disease[8]. MRI studies are supportive of the disease. Due to lack of facility genetic study is not feasible. The growth failure in our case is also a common finding of this syndrome. The low serum copper level or serum ceruloplasmin level may occur in protein energy malnutrition but the presence of pili torti, characteristics hair phenotype, asymptomatic huge bilateral subdural hematoma, and characteristics cerebral vasculature are not found in malnutrition.

We have treated the infant for bronchopneumonia and because of nonavailability and lack of sufficient data we didn't started copper histidine or copper acetate at this late presented patient of 8 months[5].

\section{Prevention}

Genetic counseling and prenatal diagnosis are helpful though approximately $33 \%$ of cases may be due to mutaion. Recurrence risk of Menkes disease is 25\% for next issue. Abnormal egress of radioactive copper in cultured amniotic cells or the cultured chorionic cells is the basis for the prenatal testing.

\section{Conclusion}

This patient may be diagnosed as protein energy malnutrition because of less growth and developmental delay. In fact the baby has had history of hospital admission twice and diagnosed as PEM case. Clinical suspicion of possibilities may lead to correct diagnosis. The typical clinical picture of this patient is noteworthy.

\section{Abbreviations}

PEM: Protein energy malnutrition; ATP: Adenosine triphosphate; EEG: Electroencephalography; MRI: Magnetic Resonance Imaging; MR: angiography-Magnetic Resonance angiography.

\section{Competing interests}

The authors declare that they have no competing interests.

\section{Authors' contributions}

AKD was responsible for patient care, follow up and drafting of paper, TNG collected data and assisted AKD to prepare manuscript, KN coordinated the study and MKG involved in he radiological investigation of the study. All authors read and approved the final manuscript.

\section{Consent}

Written informed consent was obtained from the patient for publication of this case report and accompanying images. A copy of the written consent is available for review by the Editor - in - Chief of this Journal.

\section{Acknowledgements}

We acknowledge Dr. Alak Ghosh, Reader, Department of Chemistry, the University of Burdwan for serum copper estimation, Department of Dermatology, Burdwan Medical College for microscopic examination of hair, Department of Radiology, Burdwan Medical college for radiological investigations

\section{References}

I. Kirodian BG, Gogtay NJ, Udani VP, Kashirsagar NA: Treatment of Menkes disease with parental copper histidine. Indian Pediatrics 2002, 39: 183-185. 
2. Danks DM, Campbell PE, et al.: Menkes's kinkey hair syndrome An Inherited defect of copper absorption with widespread effects. Pediatrics 1972, 50(2): I88-20I.

3. Kodama H, Murata $Y$, Kabayashi M: Clinical manifestations and treatment of Menkes disease and its variants. Pediatr Int 1999, 4I(4):423-429.

4. Drank DM, Cartwright E, Stevens BJ, Townley RR: Menke's kinkey hair diaease: Further definition of the defect in copper transport. Science 79(78): | |40-2. March I6, 1973, [Medline]

5. Christodoulou J, Danks DM, Sarkar B, et al.: Early treatment of Menkes disease with parenteral copper-histidine: long-term follow-up of four treated patients. Am J Med Jenet 1998, 76:154-164.

6. Mollar LB, Tumer Z, Lund C, et al.: Similar splice-site mutation s of ATP7A gene lead to different phenotypes: classical Menkes disease or occipital horn syndrome. Am J Human Genet 2000, 66: $1211-20$.

7. Culotta VC, Gitlin JD, et al.: Disorders of copper metabolism in Scriver CR et.el. edn. In The molecular and metabolic basis of inherited disease 8th edition. New York McGraw-Hill; 200I:3 I05-3 26.

8. Koeller D: Metal metabolism disorder. In Inborn errors of metabolism In: Neil Mclntosh, Peter Helms, Rosalind Smyth edn. Forfer and Arneil's Textbook of Pediatrics 6th edition. Edited by: Robert D Steiner. Churchill-Livingstone; 2003:1190-91.

Publish with Bio Med Central and every scientist can read your work free of charge

"BioMed Central will be the most significant development for disseminating the results of biomedical research in our lifetime. "

Sir Paul Nurse, Cancer Research UK

Your research papers will be:

- available free of charge to the entire biomedical community

- peer reviewed and published immediately upon acceptance

- cited in PubMed and archived on PubMed Central

- yours - you keep the copyright 